\title{
Effect of nonylphenol on the regulation of cell growth in colorectal cancer cells
}

\author{
XUEFENG YANG ${ }^{1}$, HANDONG HUANG $^{1}$, MAIJIAN WANG $^{1}$, XINGBIN ZHENG $^{1}$, \\ JIE XU ${ }^{2}$ and MING XIE ${ }^{1}$ \\ ${ }^{1}$ Department of Gastrointestinal Surgery, Affiliated Hospital of Zunyi Medical University; ${ }^{2}$ School of Public Health, \\ Zunyi Medical University, Zunyi, Guizhou 563000, P.R. China
}

Received May 24, 2016; Accepted April 6, 2017

DOI: $10.3892 / \mathrm{mmr} .2017 .6817$

\begin{abstract}
Nonylphenol (NP) is a well-known endocrine-disrupting chemical (EDC), which can enhance the progression of cancer by functioning as an estrogen-like factor. In the present study, the effects of different concentrations of NP on COLO205 colorectal cancer (CRC) cells were examined. The results of flow cytometric analysis revealed that NP significantly decreased the proportion of cells in the G0/G1 phase in a dose-dependent manner, which was accompanied by a marginal increase in the proportions of cells in $\mathrm{S}$ and G2/M phases. NP did not induce apoptosis, whereas estradiol (E2) did induce apoptosis. To elucidate the mechanisms underlying the action of NP on COLO205 cells, the transcriptional levels of extracellular signal-regulated kinase $(E R K) 1, E R K 2$ and phosphoinositide 3-kinase $(P I 3 K)$ were assessed using reverse transcription-quantitative polymerase chain reaction analysis. The expressions levels of ERK1,ERK2 and PI3K were increased by treatment with NP in a dose-dependent manner. On examining protein levels, the expression of PI3K p38 was increased by NP and E2, and the expression of ERK1/2 was increased by NP. The phosphorylation of the ERK protein was significantly increased by treatment with NP at a high concentration $\left(10^{-4} \mathrm{M} ; \mathrm{P}<0.01\right)$, but significantly decreased by $\mathrm{E} 2$ $(\mathrm{P}<0.01)$. Two key proteins in the transforming growth factor (TGF) $\beta$ pathway (c-Fos and SnoN) were selected for analysis using western blot analysis in the COLO205 cells treated with NP and E2. The expression levels of c-Fos and SnoN were significantly increased by treatment with E2 $\left(10^{-7} \mathrm{M} ; \mathrm{P}<0.01\right)$ and NP $\left(10^{-7}-10^{-4} \mathrm{M} ; \mathrm{P}<0.01\right)$. Taken together, these results indicated that NP affected the development of CRC via the ERK signaling pathway and TGF $\beta$ pathway.
\end{abstract}

Correspondence to: Ms. Ming Xie, Department of Gastrointestinal Surgery, Affiliated Hospital of Zunyi Medical University, 149 Dalian Road, Zunyi, Guizhou 563000, P.R. China

E-mail: xieming6531@126.com

Key words: nonylphenol, colorectal cancer, cell cycle, extracellular signal-regulated kinase signaling pathway, transforming growth factor $\beta$ pathway

\section{Introduction}

Endocrine-disrupting chemicals (EDCs) are exogenous compounds, which are present in the environment and food, and have an effect on the normal endocrine system $(1,2)$. EDCs have effects on male and female reproduction, developmental disorders, the development and progression of cancer, metabolism and obesity, and cardiovascular endocrinology $(1,3,4)$. EDCs can induce estrogen-like or androgen-like effects by binding to hormone receptors, including the estrogen receptor (ER) and androgen receptor (AR), therefore, they may interfere with the actions of endogenous steroid hormones or induce hormone-mediated responses. The abnormal activation of estrogen signaling by EDCs leads to altered gene expression in target tissues and carcinogenesis (5).

Nonylphenol (NP) is a well-known EDC. It is a degradation product of alkylphenol polyethoxylate (APE). The use of pesticides, polystyrene plastics and paints, including APE, can lead to the bioaccumulation of NP in the food chain. The accumulation of NP in the body can result in endocrine disruption, and immunological and reproductive disorders (6). It has been reported that NP has an estrogenic effect in humans (6). Previous studies have demonstrated that NP can enhance the progression of cancer by acting on the cell cycle, apoptosis and metastasis in breast, ovarian and prostate cancer (7-10).

Colorectal cancer (CRC) is the third most common type of malignancy with high mortality rates in men and women worldwide (11). In disease progression, the processes of the DNA repair system, inflammation and apoptosis are altered, and metastases are the primary cause of poor prognosis and cancer-associated mortality in patients with CRC (12). The risks of human CRC are associated with smoking, alcohol intake, dietary factors and obesity. A number of studies have suggested that estrogen has a potential role in the development of CRC $(13,14)$. Men are more susceptible to colon cancer than women, and the use of hormone-replacement therapy reduces the risk of CRC in postmenopausal women (15). However, the evidence that high concentrations of circulating estrogen confer an increased risk for CRC in men and women is inconsistent (16-18). Estrogen concentrations are higher in CRC tissues, compared with concentrations in nonneoplastic tissues in patients with CRC, and patient prognosis is poorer when intratumoral estrogen concentrations are higher (19). 
Therefore, xenoestrogens, including NP, may also be associated with the risk of CRC.

In the present study, the in vitro effects of NP at different concentrations on COLO205 CRC cell cycle and apoptosis were examined, and the mechanism of action was investigated by analyzing alterations in the expression of genes in the ERK pathway and TGF $\beta$ pathway.

\section{Materials and methods}

Cell culture and treatment. Human COLO205 CRC cells were obtained from the American Type Culture Collection (ATCC CCL-222; Manassas, VA, USA). The cells were cultured in Roswell Park Memorial Institute-1640 medium (Hyclone Laboratories; GE Healthcare Life Sciences, Logan, UT, USA) supplemented with $10 \%$ fetal bovine serum (Zhejiang Tianhang Biotechnology Co., Ltd., Huzhou, China), $100 \mathrm{IU} / \mathrm{ml}$ penicillin and $100 \mathrm{mg} / \mathrm{ml}$ streptomycin at $37^{\circ} \mathrm{C}$ in a humidified $5 \% \mathrm{CO}_{2}$ atmosphere. NP with analytical standard purity was purchased from Aladdin Industrial Corporation (Shanghai, China), and was dissolved in absolute ethyl alcohol to $50 \mathrm{mmol} / \mathrm{l}$.

Flow cytometric analysis of cell cycle and cell apoptosis. The effects of NP and estradiol (E2) on cell cycle progression were determined using flow cytometry. Following fixation, the cells were stained with propidium iodide (PI) solution $(50 \mu \mathrm{g} / \mathrm{ml} \mathrm{PI}$ and $100 \mu \mathrm{g} / \mathrm{ml}$ RNase A in PBS) and then subjected to cell cycle analysis. The extent of cell apoptosis was measured using Annexin V/PI double staining. Binding buffer $(300 \mu \mathrm{l})$ was used for cell resuspension $\left(6 \times 10^{4}\right.$ cells), and $5 \mu \mathrm{l}$ of Annexin V-FITC was added to the cell suspension for $10 \mathrm{~min}$ incubation in the dark. Subsequently, $5 \mu \mathrm{l}$ of PI was added to the cell suspension for $5 \mathrm{~min}$ in the dark. The samples were analyzed with a FACSCalibur flow cytometer (BD Biosciences, Franklin Lakes, NJ, USA).

Reverse transcription-quantitative polymerase chain reaction (RT-qPCR) analysis. The COLO205 cells were seeded at a density of $0.5 \times 10^{6}$ cells/well in 6 -well plates at $37^{\circ} \mathrm{C}$ in a humidified atmosphere of $5 \% \mathrm{CO}_{2}$ until $>70 \%$ confluent growth. The cells were treated with medium containing E2 $\left(10^{-7} \mathrm{M}\right)$ or NP $\left(10^{-7}, 10^{-5}\right.$ and $\left.10^{-4} \mathrm{M}\right)$ and cultured for $48 \mathrm{~h}$ at $37^{\circ} \mathrm{C}$ in a humidified $5 \% \mathrm{CO}_{2}$ atmosphere. Total RNA was extracted using TRIzol reagent (Invitrogen Life Technologies; Thermo Fisher Scientific, Inc., Waltham, MA, USA) according to the manufacturer's protocol. Total RNA was reverse transcribed using a First Strand cDNA Synthesis kit (Toboyo Co., Ltd., Dalian, China) according to the manufacturer's protocol. The cDNA was stored at $-20^{\circ} \mathrm{C}$. The qPCR analysis was performed on a StepOne ${ }^{\mathrm{TM}}$ system (Thermo Fisher Scientific, Inc.) in a $10 \mu \mathrm{l}$ volume containing $5 \mu \mathrm{l}$ of $2 \mathrm{X}$ qPCR mix of SYBR ${ }^{\circledR}$ Premix Ex Taq ${ }^{\mathrm{TM}}$ (Takara Biotechnology Co., Ltd., Dalian, China), $1.0 \mu \mathrm{l}$ of each forward and reverse primer (Table I; $2.5 \mu \mathrm{M}), 1.0 \mu \mathrm{l}$ of cDNA $(\sim 100 \mathrm{ng})$ and $3 \mu \mathrm{l} \mathrm{ddH_{2 }} \mathrm{O}$. the reaction consisted of $5 \mathrm{~min}$ at $95^{\circ} \mathrm{C}$, followed by 40 cycles of $95^{\circ} \mathrm{C}(5 \mathrm{sec}), 72^{\circ} \mathrm{C}(40 \mathrm{sec})$ and then melting curves from 60 to $95^{\circ} \mathrm{C}\left(0.1^{\circ} \mathrm{C} / \mathrm{sec}\right)$, ending with a step at $15^{\circ} \mathrm{C}$. Melting curves were used to confirm the specificity of each primer, and no primer-dimer were identified. The relative gene expression levels were calculated using the $2^{-\Delta \Delta \mathrm{Cq}}$ method (20) and $\beta$-actin
Table I. Primer sequences and product sizes of products for reverse transcription-quantitative polymerase chain reaction analysis.

\begin{tabular}{lrr}
$\begin{array}{l}\text { Target } \\
\text { gene }\end{array}$ & Sequence & $\begin{array}{c}\text { Product } \\
\text { size (bp) }\end{array}$ \\
\hline
\end{tabular}

Actin

110

Forward 5'-CGTTGACATCCGTAAAGACCTC-3'

Reverse 5'-TAGGAGCCAGGGCAGTAATCT-3'

PI3K

262

Forward 5'-CTTCACAATGCCATCCTACTCC-3'

Reverse 5'-ATTCAGCCATTCATTCCACCT-3'

ERK1

Forward 5'-CTGGCTTTCTGACCGAGTATGT-3'

Reverse 5'-AATTTAGGTCCTCTTGGGATGG-3'

ERK2

173

Forward 5'-GCACCAACCATTGAGCAGAT-3'

Reverse 5'-TCACGGTGCAGAACATTAGCT-3'

PI3K, phosphoinositide 3-kinase; ERK, extracellular signal-regulated kinase.

was used as an internal control. The sample containing six biological replicates was amplified in triplicate.

Western blot analysis. To measure the protein expression levels of ERK, PI3Kp85, c-Fos, SnoN and $\beta$-actin, the COLO205 cells were cultured to a density of $1 \times 10^{6}$ cells and then incubated with E2 $\left(10^{-7} \mathrm{M}\right)$ or NP $\left(10^{-7}-10-^{4} \mathrm{M}\right)$ for $48 \mathrm{~h}$ at $37^{\circ} \mathrm{C}$ in a humidified $5 \% \mathrm{CO}_{2}$ atmosphere. Following treatment, whole cell lysates of the COLO205 cells were prepared in 1X RIPA buffer (Beyotime Institute of Biotechnology) for $30 \mathrm{~min}$ on ice. The total protein concentrations were determined using bicinchoninic acid (Thermo Fisher Scientific, Inc.). The total protein $(40 \mu \mathrm{g})$ was separated by SDS-polyacrylamide gel electrophoresis (5\% stacking gel and $10 \%$ separating gel), following which the proteins were transferred onto polyvinylidenedifluoride membranes (EMD Millipore, Billerica, MA, USA), and these membranes were blocked with $5 \%$ skim milk powder (BD Biosciences) for $60 \mathrm{~min}$ at room temperature. The membranes were then incubated with primary antibodies overnight at $4^{\circ} \mathrm{C}$ : Rabbit anti- $\beta$-actin (cat no. TDY051; 1:10,000; TDY Biotech Co., Ltd., Beijing, China) and anti-PI3K (cat no. ab40755; 1:500; Abcam, Cambridge, MA, USA) diluted in 5\% skimmed milk, and anti-ERK1/2 (cat no. 4695; 1:1,000), anti-p-ERK1/2 (cat no. 4370; 1:1,000) (both from Cell Signaling Technology, Inc., Danvers, MA, USA) diluted in 5\% BSA. The membranes were subsequently probed with secondary antibody (HRP-goat anti rabbit; cat no. ab6721; 1:10,000; Abcam) for $30 \mathrm{~min}$ at room temperature. Target proteins were detected using Clarity ${ }^{\mathrm{TM}}$ Western ECL Substrate (Bio-Rad Laboratories, Inc., Hercules, CA, USA). The optical density was analyzed using AlphaEaseFC software version 6.0. All experiments were performed at least three times.

Statistical analysis. Each experiment was repeated three times and analyzed using Excel 2013 (Microsoft Corporation, 

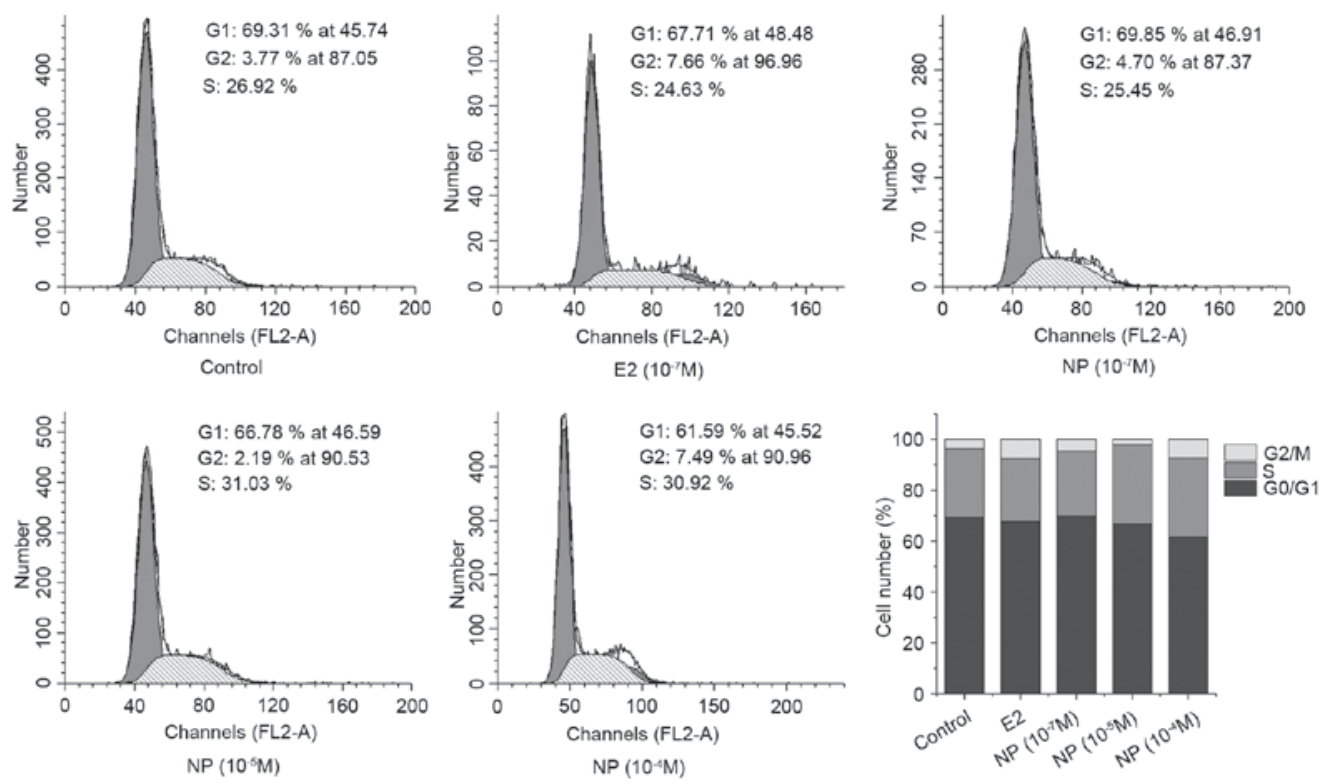

Figure 1. Effects of NP and E2 on COLO205 cell cycle. COLO205 cells were treated with E2 $\left(10^{-7} \mathrm{M}\right)$ or NP $\left(10^{-7}-10^{-4} \mathrm{M}\right)$ for $48 \mathrm{~h}$, and cell cycle distribution was analyzed using flow cytometry. Representative fluorescence histograms and the percentage of cells in each phase are shown. NP, nonylphenol; E2, estradiol.
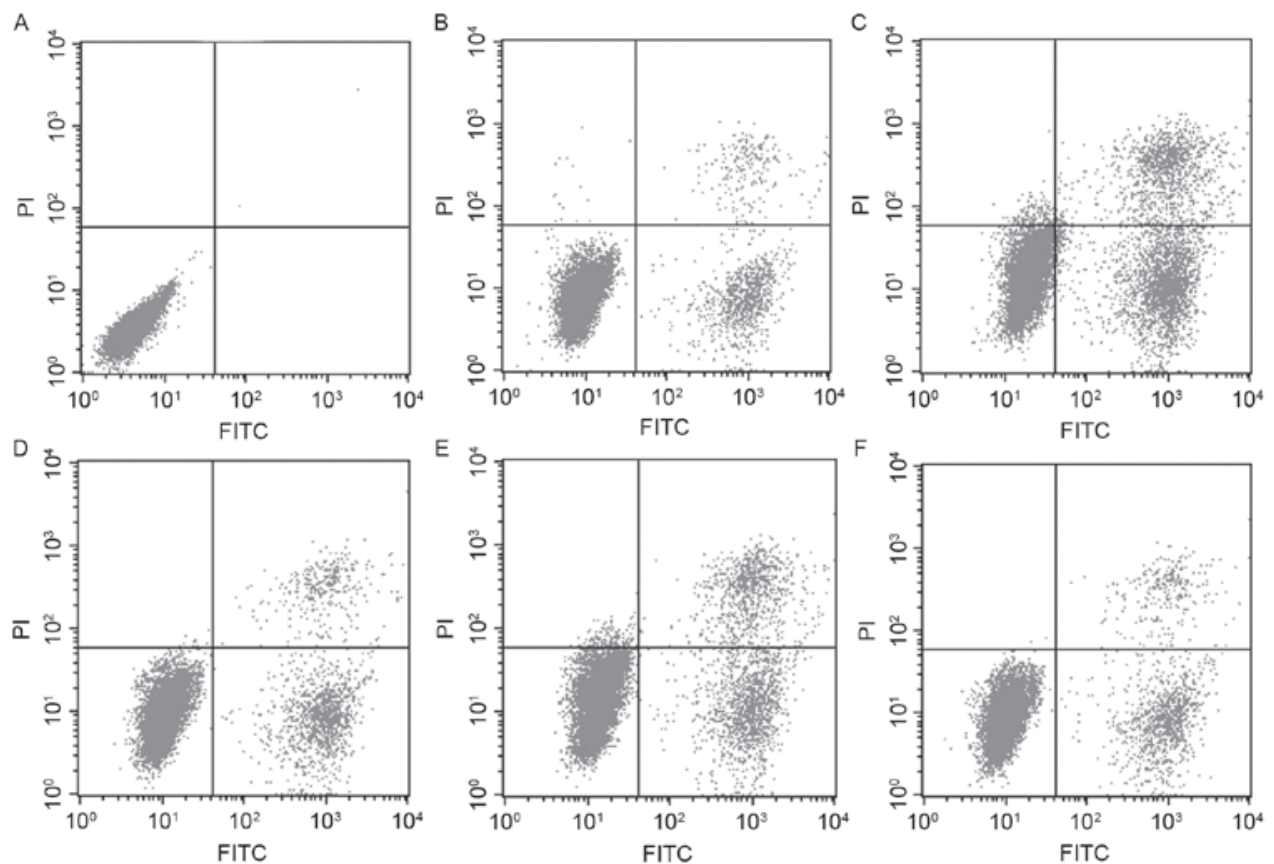

Figure 2. Effects of NP and E2 on apoptosis. (A) blank and (B) negative control (CRC cells with no treatment). COLO205 cells were treated with (C) E2 $\left(10^{-7} \mathrm{M}\right)$ or $(\mathrm{D}-\mathrm{F}) \mathrm{NP}\left(10^{-7}-10^{-4} \mathrm{M}\right)$ for $48 \mathrm{~h}$, and apoptosis was analyzed using flow cytometry. The graphs show that the percentage of apoptotic cells (right quadrants) increased in COLO205 cells treated with E2 $\left(10^{-7} \mathrm{M}\right)$ and those treated with the middle dose of NP $\left(10^{-5} \mathrm{M}\right)$, but was not affected by treatment with low or high doses of NP $\left(10^{-7} \mathrm{M}\right.$ or $\left.10^{-4} \mathrm{M}\right)$. NP, nonylphenol; E2, estradiol; PI, propidium iodide.

Redmond, WA, USA). Data are presented as the mean \pm standard deviation. Statistical analyses were performed using a one-tail t-test, $\mathrm{P}<0.05$ was considered to indicate a statistically significant difference.

\section{Results}

Effects of NP on cell cycle and apoptosis. To evaluate the effect of NP on cell growth, COLO205 cells were cultured with E2 $\left(10^{-7} \mathrm{M}\right)$ or NP $\left(10^{-7}-10^{-4} \mathrm{M}\right)$ for $48 \mathrm{~h}$, and cell cycle was examined using flow cytometry. Compared with the control group, E2 significantly increased the proportion of cells in the S phase. NP caused a significant decrease in the proportion of cells in the G0/G1 phase in a dose-dependent manner, which was accompanied by marginal increase in the proportions of cells in the $\mathrm{S}$ and G2/M phases (Fig. 1). Flow cytometry was also used to investigate whether NP affects cell apoptosis (Fig. 2A-F). The results showed that the 
A

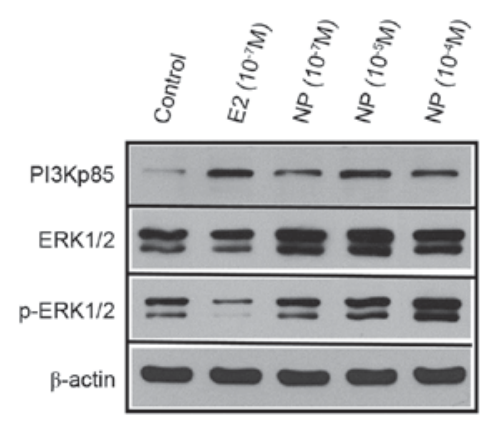

$\mathrm{C}$

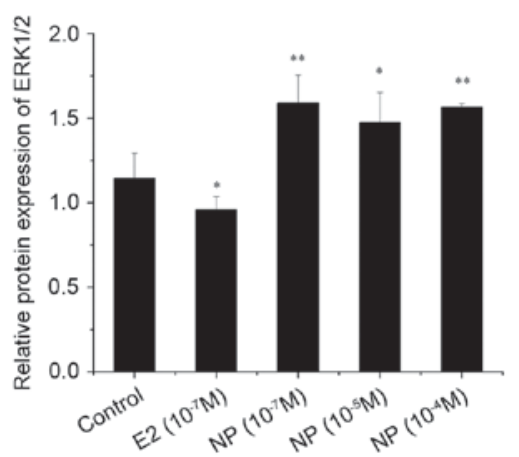

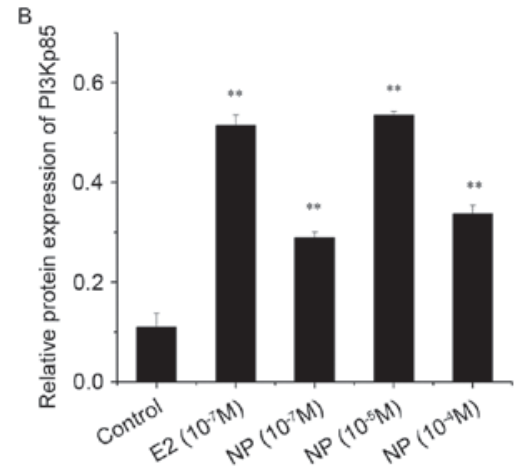

D

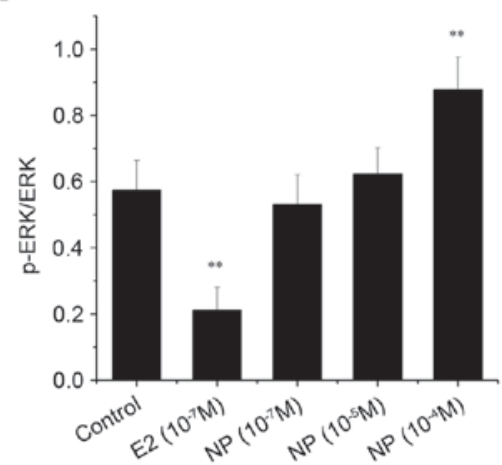

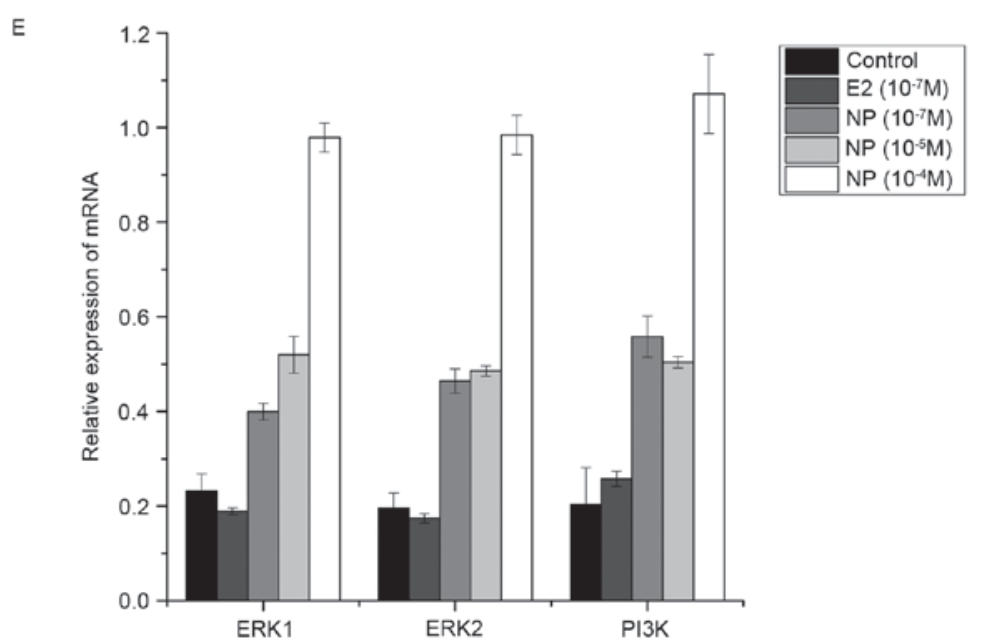

Figure 3. Expression levels of genes in the ERK pathway following treatment with E2 and NP. (A) Protein expression levels of PI3Kp85, ERK1/2 and p-ERK1/2 were detected using immunoblot analysis. Densities of (B) PI3Kp85 and (C) ERK1/2 bands were quantified, and the (D) ratio of p-ERK1/2 was analyzed. ${ }^{*} \mathrm{P}<0.05$ and $^{* *} \mathrm{P}<0.01$ compared with the control group. (E) mRNA expression levels of PI3K, ERK1 and ERK2 mRNA were analyzed using reverse transcription-quantitative polymerase chain reaction analysis. Data are presented as the mean \pm standard deviation of triplicate experiments. "P $<0.05$ and ${ }^{* *} \mathrm{P}<0.01$, compared with the control group. NP, nonylphenol; E2, estradiol; PI3K, ERK1/2, extracellular signal-regulated kinase 1/2; p-, phosphorylated.

apoptotic rate increased in the $\mathrm{E} 2$ treatment group and in the middle dose NP $\left(10^{-5} \mathrm{M}\right)$ treatment group, compared with the control group, however, no significant changes were observed in the low and high dose NP $\left(10^{-7} \mathrm{M}\right.$ and $\left.10^{-4} \mathrm{M}\right)$ treatment groups.

Alterations in expression of the ERK pathway by NP. The effects of E2 and NP on expression of the ERK pathway in the COLO205 cells were determined using RT-qPCR and western blot analyses (Fig. 3). The protein expression levels of PI3Kp85 and ERK1/2 were significantly increased by NP $(\mathrm{P}<0.01$; Fig. 3A-C). Phosphorylation of the ERK protein was significantly increased by treatment with $\mathrm{NP}$ at a high concentration $\left(10^{-4} \mathrm{M} ; \mathrm{P}<0.01\right.$; Fig. $3 \mathrm{~A}$ and $\left.\mathrm{D}\right)$, however it was significantly decreased by E2 $(\mathrm{P}<0.01)$. The results of the RT-qPCR analysis showed the same expression patterns in the mRNA expression levels of PI3K, ERK1 and ERK2 (Fig. 3E).

Alterations in expression of the TGF pathway in response to $N P$. Two key proteins in the TGF $\beta$ pathway (c-Fos and SnoN) were selected for examination using western blot analysis in COLO205 cells treated by NP and E2 (Fig. 4A). The expression levels of c-Fos and SnoN were significantly enhanced 
A

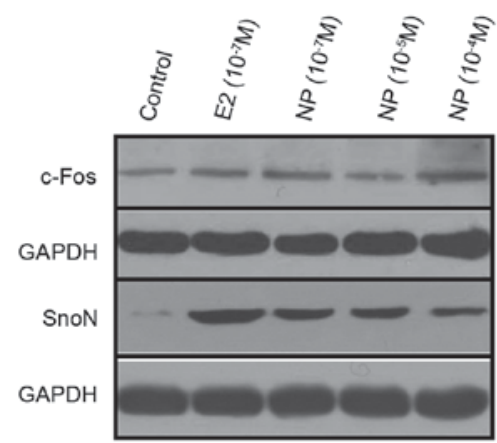

B
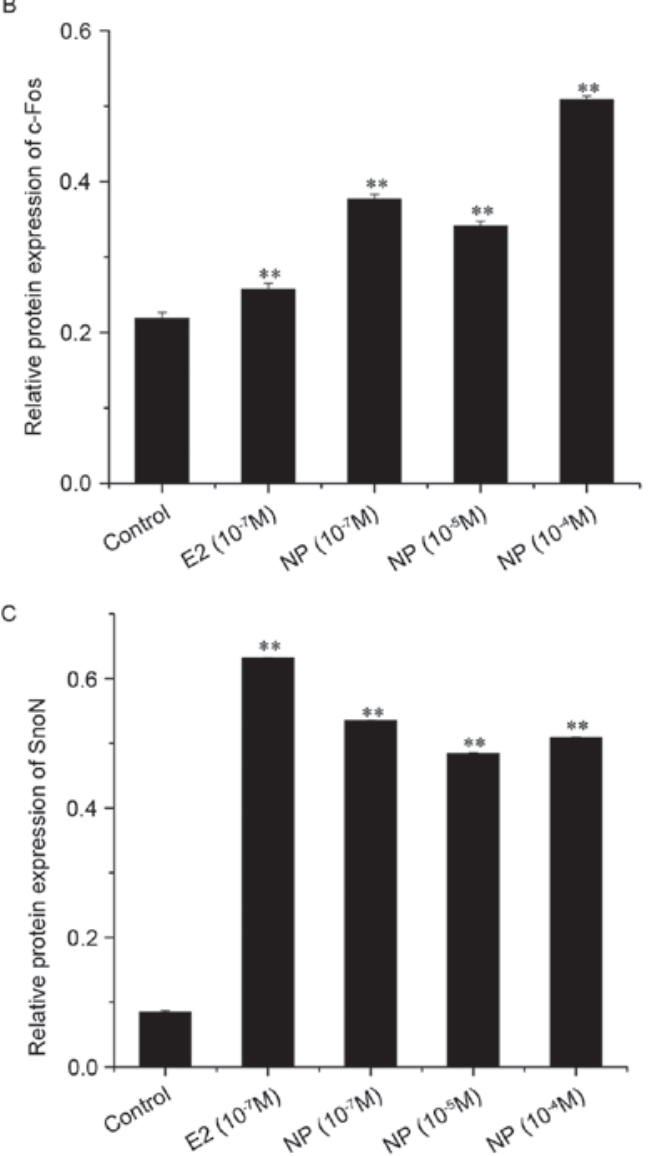

Figure 4. Protein expression levels of SnoN and c-Fos following treatment with E2 and NP. (A) Protein expression levels of SnoN and c-Fos were detected using immunoblot analysis. Densities of the (B) c-Fos and (C) SnoN bands were quantified. Data are presented as the mean \pm standard deviation of triplicate experiments. ${ }^{* *} \mathrm{P}<0.01$, compared with the control group. NP, nonylphenol; E2, estradiol.

by treatment with E2 $\left(10^{-7} \mathrm{M} ; \mathrm{P}<0.01\right)$ and $\mathrm{NP}\left(10^{-7}-10^{-4} \mathrm{M}\right.$; $\mathrm{P}<0.01)$ as shown in Fig. $4 \mathrm{~B}$ and $\mathrm{C}$.

\section{Discussion}

EDCs can interfere with hormone systems and produce adverse developmental, reproductive, neurological and immunological effects in mammals (21). Previous studies have shown that these substances also adversely affect human health, resulting in reduced fertility and increased progression of certain diseases, including obesity, diabetes, endometriosis and certain types of cancer (9,22-24). EDCs can interrupt the normal functions of reproductive organs by aberrantly binding to hormone receptors and further triggering hormone-responsive cancer initiation and progression, including in breast, ovarian and prostatic cancer (8-10). The present study examined whether one of the EDCs, NP, enhances the progression CRC.

The results of the present study revealed that the proportion of COLO205 CRC cells in the G0/G1 stage was significantly reduced by NP in a dose-dependent manner, which indicated that NP promoted CRC cell growth, as reported in previous cancer studies $(8,25)$. However, despite the alterations observed in cell viability, the apoptotic rates of the cells were unaffected by NP. These results suggested that NP promoted cell proliferation, but had no effect on apoptosis.

Mutation activation of the ERK signaling pathway is frequently observed in human cancer, including CRC (26), and is important in the regulation of malignant cellular proliferation, migration and invasion. Previous studies have demonstrated that estrogens and xenoestrogens can activate the phosphorylation of ERK1/2 in rat pituitary tumor cells, and that responses are inhibited by ERK inhibitors $(27,28)$. The present study found that the phosphorylation of ERK1/2 was significantly increased in CRC cells treated with NP in a dose-dependent manner; however, this phosphorylation was decreased by E2. This difference may be due to the two types of cell being derived from different genetic backgrounds and undergoing several other genomic hits by treatment with E2. These results indicated that NP promoted the proliferation of CRC cells through activating the ERK signaling pathway, however, the mechanism of activation and the reason underlying the different effects induced by E2 and NP require further investigation.

The TGF $\beta$ signaling pathway is also a key determinant of carcinoma cell behavior, acting as a tumor suppressor pathway, and a promoter of tumor progression and invasion (29). In ovarian cancer models, EDCs have been shown to inhibit the TGF $\beta$ signaling pathway by preventing the degradation of SnoN protein and increasing the protein expression of c-Fos (8). Members of the Fos family, including c-Fos, FosB, and its smaller splice variants, Fra-1 and Fra-2, dimerize with Jun proteins to form the activating protein 1 transcription factor complex, which is central during malignant transformation and progression (30). In addition, SnoN is a negative regulator of the TGF $\beta$ signaling pathway and is directly linked to its ability to repress the transcription of TGF $\beta$-inducible genes (31). In the present study, it was also found that NP induced the expression of c-Fos and SnoN, as did E2. Therefore, it was hypothesized that NP may inhibit the TGF $\beta$ signaling pathway in CRC cells as it does in ovarian cancer cells.

In conclusion, the results of the present study suggested that NP may affect the growth of CRC cells by activating the ERK signaling pathway via increasing the phosphorylation of ERK1/2 and inhibiting the TGF $\beta$ signaling pathway via the upregulation of c-Fos and SnoN. This is the first report, to the best of our knowledge, to demonstrate the potential mechanism between NP and CRC. The results of the present study demonstrated the effect of NP on the progression of CRC. Further investigations are required to establish the mechanism underlying the effects of NP on the ERK and TGF $\beta$ signaling pathways. 


\section{Acknowledgements}

This study was supported by Natural Scientific Foundation in the Science and Technology Department of Guizhou Province, China (grant no. J20142185).

\section{References}

1. Diamanti-Kandarakis E, Bourguignon JP, Giudice LC, Hauser R, Prins GS, Soto AM, Zoeller RT and Gore AC: Endocrine-disrupting chemicals: An endocrine society scientific statement. Endocr Rev 30: 293-342, 2009.

2. Diamanti-Kandarakis E, Palioura E, Kandarakis SA and Koutsilieris M: The impact of endocrine disruptors on endocrine targets. Horm Metab Res 42: 543-552, 2010.

3. Yoon K, Kwack SJ, Kim HS and Lee BM: Estrogenic endocrine-disrupting chemicals: Molecular mechanisms of actions on putative human diseases. J Toxicol Environ Health B Crit Rev 17: 127-174, 2014.

4. Safe SH, Pallaroni L, Yoon K, Gaido K, Ross S, Saville B and McDonnellc D: Toxicology of environmental estrogens. Reprod Fertil Dev 13: 307-315, 2001

5. Choi SM, Yoo SD and Lee BM: Toxicological characteristics of endocrine-disrupting chemicals: Developmental toxicity, carcinogenicity, and mutagenicity. J Toxicol Environ Health B Crit Rev 7: 1-24, 2004.

6. Bonefeld-Jørgensen EC, Long M, Hofmeister MV and Vinggaard AM: Endocrine-disrupting potential of bisphenol A, bisphenol A dimethacrylate, 4-n-nonylphenol, and 4-n-octylphenol in vitro: New data and a brief review. Environ Health Perspect 115 (Suppl 1): S69-S76, 2007.

7. Kim YS, Hwang KA, Hyun SH, Nam KH, Lee CK and Choi KC: Bisphenol A and nonylphenol have the potential to stimulate the migration of ovarian cancer cells by inducing epithelial-mesenchymal transition via an estrogen receptor dependent pathway. Chem Res Toxicol 28: 662-671, 2015.

8. Park MA and Choi KC: Effects of 4-nonylphenol and bisphenol A on stimulation of cell growth via disruption of the transforming growth factor- $\beta$ signaling pathway in ovarian cancer models. Chem Res Toxicol 27: 119-128, 2014.

9. Kim SH, Nam KH, Hwang KA and Choi KC: Influence of hexabromocyclododecane and 4-nonylphenol on the regulation of cell growth, apoptosis and migration in prostatic cancer cells. Toxicol In Vitro 32: 240-247, 2016.

10. In SJ, Kim SH, Go RE, Hwang KA and Choi KC: Benzophenone-1 and nonylphenol stimulated MCF-7 breast cancer growth by regulating cell cycle and metastasis-related genes via an estrogen receptor $\alpha$-dependent pathway. J Toxicol Environ Health A 78: 492-505, 2015

11. Siegel RL, Miller KD and Jemal A: Cancer statistics, 2016. CA Cancer J Clin 66: 7-30, 2016.

12. Van Cutsem E and Oliveira J; ESMO Guidelines Working Group: Advanced colorectal cancer: ESMO clinical recommendations for diagnosis, treatment and follow-up. Ann Oncol 20 (Suppl 4): S61-S63, 2009.

13. Kennelly R, Kavanagh DO, Hogan AM and Winter DC: Oestrogen and the colon: Potential mechanisms for cancer prevention. Lancet Oncol 9: 385-391, 2008.

14. Lin JH and Giovannucci E: Sex hormones and colorectal cancer: What have we learned so far? J Natl Cancer Inst 102: 1746-1747, 2010.

15. Grodstein F, Newcomb PA and Stampfer MJ: Postmenopausal hormone therapy and the risk of colorectal cancer: A review and meta-analysis. Am J Med 106: 574-582, 1999.

16. Gunter MJ, Hoover DR, Yu H, Wassertheil-Smoller S, Rohan TE, Manson JE, Howard BV, Wylie-Rosett J, Anderson GL, Ho GY, et al: Insulin, insulin-like growth factor-I, endogenous estradiol and risk of colorectal cancer in postmenopausal women Cancer Res 68: 329-337, 2008
17. Clendenen TV, Koenig KL, Shore RE, Levitz M, Arslan AA and Zeleniuch-Jacquotte A: Postmenopausal levels of endogenous sex hormones and risk of colorectal cancer. Cancer Epidemiol Biomarkers Prev 18: 275-281, 2009.

18. Wu H, Xu L, Chen J, Hu J, Yu S, Hu G, Huang L, Chen X, Yuan X and Li G: Association of estrogen receptor beta variants and serum levels of estradiol with risk of colorectal cancer: A case control study. BMC Cancer 12: 276, 2012.

19. Sato R, Suzuki T, Katayose Y, Miura K, Shiiba K, Tateno H, Miki Y, Akahira J, Kamogawa Y, Nagasaki S, Yamamoto K, et al: Steroid sulfatase and estrogen sulfotransferase in colon carcinoma: Regulators of intratumoral estrogen concentrations and potent prognostic factors. Cancer Res 69: 914-922, 2009.

20. Livak KJ and Schmittgen TD: Analysis of relative gene expression data using real-time quantitative PCR and the 2-(Delta Delta C(T)) method. Methods 25: 402-408, 2001.

21. Yang O, Kim HL, Weon JI and Seo YR: Endocrine-disrupting chemicals: Review of toxicological mechanisms using molecular pathway analysis. J Cancer Prev 20: 12-24, 2015.

22. Ariemma F, D'Esposito V, Liguoro D, Oriente F, Cabaro S, Liotti A, Cimmino I, Longo M, Beguinot F, Formisano P and Valentino R: Low-dose bisphenol-A impairs adipogenesis and generates dysfunctional 3T3-L1 adipocytes. PloS One 11: e0150762, 2016.

23. Jambor T, Lukáčová J, Tvrdá E, Knážická Z, Forgács Z and Lukáč N: The impact of 4-nonylphenol on the viability and hormone production of mouse leydig cells. Folia Biol (Praha) 62: 34-39, 2016.

24. Lee HR, Hwang KA, Park MA, Yi BR, Jeung EB and Choi KC: Treatment with bisphenol A and methoxychlor results in the growth of human breast cancer cells and alteration of the expression of cell cycle-related genes, cyclin D1 and p21, via an estrogen receptor-dependent signaling pathway. Int J Mol Med 29: 883-890, 2012.

25. Dong Y, Araki M, Hirane M, Tanabe E, Fukushima N and Tsujiuchi T: Effects of bisphenol A and 4-nonylphenol on cellular responses through the different induction of LPA receptors in liver epithelial WB-F344 cells. J Recept Signal Transduct Res 34: 201-204, 2014

26. Wei Z, Ma W, Qi X, Zhu X, Wang Y, Xu Z, Luo J, Wang D, Guo W, Li X, et al: Pinin facilitated proliferation and metastasis of colorectal cancer through activating EGFR/ERK signaling pathway. Oncotarget 7: 29429-29439, 2016.

27. Jeng YJ and Watson CS: Combinations of physiologic estrogens with xenoestrogens alter ERK phosphorylation profiles in rat pituitary cells. Environ Health Perspect 119: 104-112, 2011.

28. Watson CS, Jeng YJ, Hu G, Wozniak A, Bulayeva N and Guptarak J: Estrogen- and xenoestrogen-induced ERK signaling in pituitary tumor cells involves estrogen receptor- $\alpha$ interactions with G protein- $\alpha i$ and caveolin I. Steroids 77: 424-432, 2012.

29. Derynck R, Akhurst RJ and Balmain A: TGF-beta signaling in tumor suppression and cancer progression. Nat Genet 29: 117-129, 2001.

30. Milde-Langosch K: The Fos family of transcription factors and their role in tumourigenesis. Eur J Cancer 41: 2449-2461, 2005

31. Deheuninck J and Luo K: Ski and SnoN, potent negative regulators of TGF-beta signaling. Cell Res 19: 47-57, 2009. 